\title{
JAN VAN EYCK JAKO MALARZ RELIGIJNY I PORTRECISTA
}

\author{
I. OBRAZY MARYJNE \\ 1. Maria obrazem Kościoła. \\ (Madonna w Kościele, Zwiastowanie z ok. 1428 r.)
}

Około r. 1428 Jan Eyck wykonał dwa obrazy, w których N. Maria Panna występuje jako odbicie doskonałości Kościoła. Trzydziestoośmioletni malarz, służąc wówczas w różnych legacjach księcia Filipa Dobrego, zwiedzał Europę, zastanawiał się nad tajemnicą chrześcijańskiej społeczności i widział jej głęboki związek z Bogarodzicą. Wymalował wówczas niewielki, wysoki na $31 \mathrm{~cm}$ obrazek, przechowywany obecnie w Berlinie (Staatliche Museum, dawniej Kaiser-Friedrich Museum), a przedstawiający Marię na tle bogatej architektury kościoła. Chór katedry jest zamknięty przez kamienne, rzeźbione lectorium (Lettner). Przez otwór przegrody widać dwóch aniołów celebrujących mszę w chórze; poza tym nie ma nikogo w gotyckiej bazylice, jedynie w środku nawy stoi wygięta łukowato o pięknej i eleganckiej linii, obowiązującej w początkach XV wieku, Maria z Dzieciątkiem. Dziecko jest ujęte realistycznie, bez upiększeń. Swiatło pada do świątyni od północy, co jest odwróceniem praw natury: wskazuje to, że chodzi tu nie o dzienne, ale o inne światło, które oświeca Miasto Boże. Od północy poprzez arkadę widać otwarte wejście oświetlone od zewnątrz. Jasne promienie wpadają również przez barwne witraże pasa okiennego. W mistrzowski sposób oddał malarz półmrok, zalegający w kościele.

Miłośnicy sztuki Eyckowej zwracają uwagę, że Matka Boska jest tutaj za wielka w stosunku do rozmiarów katedry. Tę dysproporcje często kładzie się na karb niedojrzałości artysty, bo to dzieło należy do jego najwcześniejszych prac, poprzedzających tryptyk gandawski. Zarzutu tego jednak nie można brać poważnie, bo mistrz, który umiał zastosować prawa perspektywy i obliczyć stosunki między poszczególnymi 
częściami kościoła, potrafiłby również znaleźć odpowiednie proporcje dla Madonny. W rzeczywistości — jak zauważa Panofsky - obraz przedstawia Marię jako Kościól. Komentatorzy Pieśni nad Pieśniami utożsamiają Chrystusa z oblubieńcem, oblubienicę z Kościołem, a także z Marią. Maria jest Matką i Oblubienicą, Królową w niebie, Kościołem na ziemi! A zatem dysproporcja figury Marii w stosunku do architektury na obrazie van Eycka nie jest omyłką, lecz symbolem, który wskazuje na nadprzyrodzoną rolę Marii, jako mistrzyni i personifikacji Kościola swego Syna 2 .

Drugim obrazem Marii na tle katedralnej architektury jest obraz Zwiastowania w National Gallery w Waszyngtonie, pochodzący ze zbiorów leningradzkiego Ermitażu 3. Prawdopodobnie jest to jedno ze skrzydeł zaginionego tryptyku. Po raz pierwszy w dziejach malarstwa sztalugowego Zwiastowanie odbywa się w kościele. Maria stoi pośrodku nawy kościelnej z rękoma podniesionymi na wzór orantki. Jej płaszcz został zarzucony na stolik, na którym liży książka do modlitwy. Od strony północnej wchodzi do wnętrza archanioł w koronie na głowie, z berłen w lewej ręce, odziany bardzo bogatą kapą (według ówczesnej mody burgundzkiej) na wzór aniołów śpiewających w Adoracji Baranka, z tą różnicą, że podnosi skrzydła $z$ pawich piór. Prawicą wskazuje on na wypisane słowa, biegnące od jego ust: „Ave, gratia plena”. Natomiast słowa mówione przez Marię — „Ecce ancilla Domini” - są nakreślone w ten sposób, żeby je można było odczytać z góry, czyli są zwrócone do Boga. Wśród promieni spadających z górnego północnego okna spływa na głowę Najświętszej Panny gołąb Ducha Świętego.

Prostokątne tryforia kościoła przypominają katedrę w Tournai. Stylowo odpowiadają one wiekowi XII. W ścianie wschodniej ponad tryforiami jaśnieje romańskie okno jakby pochodzące z XI wieku, na którego witrażowych szybach przebija się postać Pantokratora w mandorli. Pod tryforiami biegną gotyckie arkady. Dziwną anomalią jest to, że nad partią gotycką oglądamy również od północy romańskie, styistycznie wcześniejsze okna. Zdaniem ogółu historyków sztuki ten anachronizm był przez Eycka zamierzony i miał wyrażać jedność obu Testamentów - Starego i Nowego. Poniżej tryforiów trzy przeświecające we wschodniej ścianie okna za arkadami na wysokości głowy Marii oznaczają Trójcę Sw., która jest przyczyną sprawczą Inkarnacji Syna Bożego.

1 E. Panofsky, Early Netherlandish Painting, Cambridge Mass. 1953, s. 1. s. 14.7, 147. Por. homilia b1. opata Izaaka: O Marii i Kościele, Patrologia Latina 1841862 n.

2 E. Panofsky, Rzeczywistość i symbol w malarstwie niderlandzkim. W: Stzdic $z$ historii sztuki, Warszawa 1971 , s. $137-141$, ryc. 139.

3 E. Panofsky, The Friedsam Annunciation and the Problem of the Gent Altarpiece, "The Art Bulletin” 17 (1935), s. 433; tenże, Early Painting, 138, 144; tenże, Rzeczywistość $i$ symbol, s. 129-131, ryc. 132; A. Dohman, Die Altniederíndiscie Malerei des fünfzeinten Jahrhunderts von Van Eyck jis Bosch, Leipzig 1964, 27. 
Maria w chwili Wcielenia stała się świątynią Boga Trójosobowego templum S. Trinitatis. Wyposażenia artystyczne katedry Zwiastowania są świadectwem, że Pismo św. ukazuje w sposób coraz więcej jasny rolę Matki Zbawiciela w ekonomii Zbawienia. Obok Zbawiciela na kuli ziemskiej, widocznego w witrażu, dwa malowidła przedstawiają Ználezienie Mojżesza i Nadanie Mojżeszowi przykazań. Pierwszy obraz oznacza znalezienie przez ludzkość Chrystusa, którego nam dała Najświętsza Maria Panna, drugi - że Chrystus, który w chwili Zwiastowania staje się Ciałem w łonie Panny Marii, będzie twórcą prawa Nowego Testamentu. Pomiędzy łukami wschodniej arkatury kościoła dwa medaliony prezentują popiersia Izaaka i Jakuba, praojców wybranego ludu. Podobnie Maria i Jezus będą duchowymi protoplastami ludu Bożego Nowego Przymierza. Na flizach posadzki wśród znaków zodiaku, który oznajmia o panowaniu poczętego Chrystusa nad całym kosmosem, są narysowane jakby niellem trzy sceny z życia Samsona i jedna z życia Dawida. Samson, zabijający Filistynów, to Chrystus przychodzący na świat, aby pokonać grzech pierworodny; Samson i Dalila - Chrystus wydany przez swój naród na śmierć; śmierć Samsona - zwycięstwo przez śmierć: triumf Dawida nad Goliatem - koniec panowania szatana na ziemi. Pełnia czasu, z którą nastała nowa ekonomia zbawienia, nastała z Najświętszą Marią Panną, Bogarodzicą. Seria zodiaku jest tak ułożona, że anioł klęka na znaku Barana, który rozpoczyna wiosnę (przypomina nam to dzień Zwiastowania), a przed Marią wypada znak Koziorożca, w którym obchodzimy Boże Narodzenie. Przed stolikiem Marii stoi duży wazon lilii z kwiatami i stoliczek z poduszką, co oznacza dziewicze poczęcie przez Marię Syna Bożego.

Zwiastowanie w kościele przedstawione przez Jana Eycka w obrazie waszyngtońskim wyraża, że mysterium przyjęcia ciała przez Chrystusa z Mari Dziewicy ustawicznie się objawia w Kościele, którego Maria jest typicznym wyobrażeniem. Dlatego i katedra, gdzie N. Panna stoi w czasie przybycia anioła, jest symbolem Jej własnym i Kościoła.

2. Maria w domu mieszczańskim.

(Ince Hall Madonna i Madonna Lucca z r. 1433)

W roku 1429 Jan Eyck brał udział w poselstwie, które przywiozło do Lille Izabelę portugalską, narzeczoną Filipa Dobrego. Po spełnieniu tego zadania, malarz powziął zamiar przeniesienia się do Brugii, gdzie rozpoczął żywot mieszczanina, choć kontaktu z dworem nie stracił i zapewne brał udział w godach małżńskich Filipa w styczniu 1430 r. W roku następnym zdobył Eyck własny dom i w nim już kończył prace około tryptyku gandawskiego. W tryptyku tym pokazał Zwiastowanie w zwy- 
kłej komnacie. Wpływ nowych warunków życiowych w mieście odbił się u Eycka także i w dwu następnych obrazach. Wykonal je po skonczeniu tryptyku dla Jodoka Vyda. Są to malowane około r. 1433 dwie tablice, przedstawiające Matkę Boską siedzącą we wnętrzu mieszczanskim na pewnego rodzaju niskim tronie pod baldachimem, piastującą na łonie Dzieciątko. W obu obrazach płaszcz Matki Boskiej jest szeroko rozrzucony i zajmuje wiele miejsca. W średniowieczu mało zwracano uwagi na ideał postaci ludzkiej (według Kerbera ,raumplastisches Figurenideal"), a raczej zastępowano go przepychem materiałowym i utwierdzano przez plastyczność ubiorów. Draperia i kolor z nią związany grały wielką rolę ${ }^{4}$. Dopiero renesans wprowadził absolutne panowanie ludzkiego ciała. Eyckowe obrazy Matki Boskiej, odwiedzającej dom mieszczański, posiadają wiele symboliki właściwej dla zwyczajnego domu w późnośredniowiecznym mieście.

Jeden $\mathrm{z}$ tych obrazów, zwany Ince Hall Madonna ${ }^{5}$, znajduje się w $\mathrm{Na-}$ tional Gallery w Melbourne w Australii, drugi, tzw. Madonna Lucca ${ }^{\mathbf{6}}$, jest przechowywany w Städelsches Kunstinstitut w Frankfurcie nad Menem. W jednym i drugim obrazie Matka Boska siedzi samotnie na tle brokatowej opony, w mieszczańskim stroju, bez korony i zajęta jest wyłącznie swoim Dziecięciem, siedzącym na Jej kolanach. W melberneńskim egzemplarzu, obnażone Dzieciątko przygląda się iluminacjom, przewracając karty sporego pergaminowego kodeksu; we frankfurtskim ssie pierś Matki, trzymając w rączce jabłko.

W obu obrazach na lewo od Matki Boskiej widać okno, a na jego framudze leżą jabłka, które są oznaką rodzinnej miłości. Te same uczucia oznacza jabłko w ręku małego Jezusa. Na prawo w ciasnym pokoju świecznik, naczynie na wodę i misa do lavabo. Kandelabr stojący obok tronu Marii oznacza światłość daną ludzkości przez Chrystusa; Maria była Tą, "która tę światłość piastowała. Przeźroczysta karafka wody, widziana w obrazie Madonna Lucca (Matki Boskiej Karmiącej) jest symbolem Marii, która mimo zrodzenia Dzieciątka zachowała dziewiczość; jak promień słońca przechodzi przez szkło, ale go nie łamie, tak i Maria, zrodziwszy Dziecię Jezus, została taką dziewicą, jaką była przedtem ${ }^{7}$.

4 O. Korber, Hubert van Eyck. Die Verwandlung der mittelalterlichen in die neuzeitliche Gestaltung, Frankfurt am Main 1937, 306-307.

5 E. Panofsky, Early Painting, s. 183; tenże, Rzeczywistość i symbol, s. 136 n., ryc. 137. Twarz Matki Boskiej w obrazie Ince Hall Madonna jest nieszczęśliwie przemalowana.

6 A. Dohmann, Die Altniederländische Malerei, s. 29.

7 O karafce wody, jako symbolu Marii, pięknie mówi pieśn angielska (E. Panofsky, Early Painting, 144):

,As the sunbeam through the glass

Passeth but not breaketh,

So the Virgin, as she was

Virgin still remaineth" 
Madonna Lucca posiada na oparciach siedzenia umieszczone dwie pary rzeźbionych lwów; przypomina to tron Salomona, opisany w III Księdze Królewskiej ${ }^{8}$. Maria jako siedząca na Tronie Salomona, ogarnia całą mądrość Bożą w dziejach Zbawienia.

Obraz Marii, siedzącej w komnacie mieszczańskiej, jest wyrażeniem życia sąsiadów Eycka w ówczesnej Brugii, którego wyznacznikiem były: miłość rodzinna, kierowanie się światłem Ewangelii Chrystusa, ukochanie Przeczystej Dziewicy i roztropność życiowa oparta na nieprzemijającym prawie Bożym - Honorabile connubium in omnibus et torus immaculatus (Hebr. 13, 4).

3. Audiencja w komnacie Królowej Niebios. (Portret z r. 1435 kanclerza Mikolaja Rolina)

Do Jana Eycka, pracującego już piąty rok w Brugii w otoczeniu rodziny i przyjaciół, zwrócił się około r. 1435 Mikołaj Rolin, potężny kanclerz księcia Filipa Dobrego, faktyczny kierownik polityki księstwa, wielki prawnik, dyplomata, przedsiębiorczy organizator życia gospodarczego, finansista, kanclerz Burgundii (od r. 1422) i Brabantu (od r. 1430). Do niego należało miasto Autun, gdzie syn jego został biskupem (później obdarzony godnością kardynalską). W kościele Notre Dame rodzinnego miasta Rolin postawił od północy przy chórze kaplicę rodową, do której zamówił u Eycka własny portret, przedstawiający go w postawie modlitewnej, klęczącego przed tronem N. Marii Panny z Dziecięciem na łonie. Obraz pierwotnie zawieszony w kaplicy, później przeniesiony do zakrystii kolegiaty, nazywano popularnie Madonna z Autun. Wreszcie w r. 1800 ten wspaniały wizerunek kanclerza, wpatrzonego w Królową nieba, znalazł się w Luwrze ${ }^{9}$.

Niektórzy historycy sztuki, zajmujący się tym obrazem, chcieli widzieć w mężczyźnie, klęczącym przed Madonną, albo księcia Jana Bawarskiego, nie posiadającego święceń kapłańskich biskupa elekta z Liège (1371-1418), który porzuciwszy biskupstwo zagarnął Jakubinie księstwo holenderskie (1419-1425), albo też księcia Jana bez Trwogi (Joannes Intrepidus, Jean sans Peur), podstępnie zamordowanego (10 IX 1419) na moście Montereaufaut-Yonne z przyzwolenia delfina, późniejszego króla Karola VII 10. Te próby interpretacyjne nie cieszą się powodzeniem, bowiem wystarczy spojrzeć na obraz Sąu Ostatecznego, zamówiony przez

8 III Król. 10, 18-20: „Uczynił też król Salomon stolicę wielką ze słoniowej kości i powlókł ją złotem żółtym bardzo. Miała ona sześć stopni, wierzch stolicy byl okrągły $z$ tyłu, a dwie ręce, $z$ tej $i \mathrm{z}$ owej, dzierżące siedzenie, i dwa lwy stały przy każdej ręce, a dwanaście młodych lwów stojących na sześciu stopniach stąd i zowąd: nie uczyniono takiej roboty we wszystkich królestwach".

9 A. Perrier, Un Chancelier au XVe siscle Nicolas Rolin 1380-1461, Paris 1904.

10 Z. Kępiński, Madonna kanclerza Rolin, „Rocznik Historii Sztuki” 7 (1969), 133. 
kanclerza burgundzkiego u Rogera van der Weyden dla Hotel-Dieu w Beaune ${ }^{11}$, na którym obok apostołów występuje król francuski i sam Rolin; porównanie rysów oranta z obrazu Madonny z Autun z wyobrażeniem fundatora $z$ Beaune utwierdza nas w przekonaniu, że chodzi o tẹ samą osobę, mianowicie o Mikołaja. Dlatego trzeba się przychylić do zdania tych historyków sztuki, którzy zgodnie uważają, że przed Marią Królową Nieba z obrazu w Luwrze klęczy wszechwładny kanclerz burgundzki ${ }^{12}$.

Ów sześćdziesięcioletni dygnitarz, ubrany w fioletowo płaszcz, skład:t ręce przed N. Marią Panną. Przed nim na pulpicie okrytym niebieską narzutą leży modlitewnik. Mimo úgięcia kolan, przywykły do surowych rozkazów Mikołaj nie może zmienić swych twardych i niesympatycznych rysów. Naprzeciw kanclerza siedzi Maria, odziana szerokim purpurowym płaszczem. Oczy skierowała na Dziecię, siedzące na Jej prawym kolanie, jakby nie zwracając uwagi na pilnie wpatrującą się w Nią postać klęczącego. Podtrzymywane przez Marię obnażone Dzieciątko w lewej ręce trzyma kulę ziemską, a prawą wyciąga do udzielenia błogosławieństwa Rolinowi. Na płaszczu Marii widnieje napis: „Exaltata sum in Libano”. Jest to cytat z kościelnego responsorium, śpiewanego w święto Wniebowzięcia NMP: ,Sicut cedrus exaltata sum in Libano et sicut cupressus in monte Sion" (por. Eccli 24, 17). Anioł z tęczowymi skrzydłami nadlatując unosi bogatą koronę, aby ją włożyć na głowę Marii. W Jej pałacu-zamku otrzymał Rolin audiencję ${ }^{13}$. Przyszedłszy do sali tronowej upadł wprawdzie na kolana, ale potężny i bezwzględny kanclerz nie ma nic w sobie z pokornej postawy, lecz swą barczystą postacią wybija się na pierwszy plan. Wbrew zwyczajowi średniowiecznemu jego figura nie uległa pomniejszeniu, ale równa jest postaci Marii ${ }^{14}$. Nie ucieka się do pośredni-

11 Roger van der Weyden (de la Pasture), malarz flamandzki (ok. 1400-1464). Urodził się w Tournai, gdzie był uczniem Roberta Campin (dawniej zwanego Mistrzem z Flemalle). W roku 1435 osiadł w Brukseli, gdzie otrzymał tytuł malarza miejskiego. Założył tam szkołę-pracownię, która do połowy XVI wieku wywierała duży wpływ na sztukę okolicznych krajów. W r. 1450 wybrał się na obchód jubileuszowy do Rzymu, odwiedzał Florencję, ale w jego dziełach nie zaznaczył się wpływ sztuki włoskiej. Mimo, że nic nie utracił ze zdobyczy malarskich Van Eycka, jednak oddalił się od jego lirycznego humanizmu i sięgnął do gotyckich tradycji XIV wieku, na skutek czego jego malarstwo poświęcone tematom religijnym z mistrzowstwem oddawało głębokie przeżycia Matki Boskiej oraz patos Kalwarii i Sądu Ostatecznego. Zmarł 16 VI 1464 i pochowany został w kaplicy cechu malarzy w kolegiacie św. Guduli w Brukseli. Por. G. Hulin de Loo, Rogier van der Weyden, "Biographie Nationale publiée par l'Academie Royale de Belgique" XXVII, Bruxelles $1938,222-245$.

1.2 J. Deneux, Nicolas Rolin, authentique donateur de la Vierge d'Autun, ,Revue des Arts" 4 (1954), 195-200.

${ }_{13}$ "Le paradis du comme un chateau eclatant". Ch. de Tolnay, Le Maitre de Flemalle et les Freres de Eyck, Bruxelles 1939, 29.

14 Postać donatora równą świętym, przedstawionym w dziełach sztuki, pierwszy wprowadził rzeźbiarz Claus Sluter, twórca figur w portalu klasztoru kartuzów w Champmol (kolo Dijon) i słynnej Studni Mojżesza na dziedzińcu tegoż klasztoru. 
ctiva swego patrona św. Mikołaja, lecz sam przekroczył progi niebieskiego zamku. Styl architektury przybytku Marii jest na ogół romański, z dodatkiem pewnych szczegółów gotyckich. Wyprzedza więc czasy Eycka. Ponad głową Marii pochód wojska z kroczącym na czele wodzem, przed którym klęka jakaś niewiasta czy dziewczyna. Interpretacja ostatniej sceny napotykała na trudności. Charles de Tolnay widział tu Esterę, klęczącą przed Ahasverem. Scena ta miała, jego zdaniem, przedstawiać symbol Odkupienia ${ }^{15}$. Panofsky znów dopatruje się tu zdarzenia z dziejów Rzymu, tzw. sprawiedliwości Trajana ${ }^{16}$. Najbardziej wydaje się przekonywujące wyjaśnienie Z. Kępińskiego ${ }^{17}$. Wyraża on opinię, że rzeźba przedstawia córkę Jeftego, witającą ojca wracającego z wyprawy wojennej ${ }^{18}$. Córka Jeftego jest prefiguracją Marii, ofiarującej się Bogu przy wstąpieniu do świątyni. Trzeba podkreślić, że słynny utwór typologiczny Speculum humanae salvationis ${ }^{19}$ wyraźnie kojarzy córkę Jeftego z Najświętszą Marią Panną. Jak ofiara córki Jeftego była konieczna do zwycięstwa nad Ammonitami, tak ofiara Marii była konieczna dla naszego zbawienia ${ }^{20}$.

Po lewej stronie ponad klęczącym kanclerzem, na trzech wypukłorzeżbach zostały ukazane następstwa grzechu pierworodnego: utrata szczęśliwości rajskiej, mord bratni, opilstwo (Noego), a nad tronem Marii widnieje figura Jej ofiary, która nam dała zbawienie przez Króla świata Jezusa Chrystusa.

W żadnym z dzieł Eycka nie otwiera się przed naszymi oczyma tak daleki krajobraz jak w obrazie Madonny z Autun. Przez trzy przezrocza

15 Ch. de Tolnay, Le Maitre de Flemalle, s. 50, przypis 67.

16 E. Panofsky, Early Painting, 139, przyp. 2.

17 Z. Kępiński, Madonna kanclerza Rolin, 133.

1. Księga Sędziów 11, 30-31 i 33-35: „(Jefte) ślubował ślub Panu, mówiąc: Jeśli dasz synów Ammona w moje ręce, ktokolwiek pierwszy wyjdzie z drzwi domu mojego, a zabieży mi wracającemu się w pokoju od synów Ammona, tego ofiaruję na całopalenie Panu - - I poniżeni są synowie Ammona przez synów Izraelowych. A gdy się wracał Jefte do Masfa do domu swego, wybiegła naprzeciw niego jedyna córka jego z bębnami i tańcami, bo nie miał innych dzieci. Ujrzawszy ją, rozdarł szaty swe i rzekł: Biada mnie, córko moja, oszukałaś mnie i samaś oszukana jest, bom otworzył usta moje do Pana, a inaczej uczynić nie będę mógł".

19 Speculum humanae salvationis jest to typologiczna kompilacja, pisana rymowaną prozą, zawierająca w 42 rozdziałach dzieje zbawienia ludzkiego. Tekst pochodzi z początku XIV wieku; został ułożony prawdopodobnie przez Ludolfa z Saksonii, najpierw dominikanina, potem kartuza (zm. 1378). Każdy rozdział znajduje się na dwóch stronach otwartej księgi i składa się z 4 kolumn po 25 wierszy (razem tych wierszy jest 100). W pierwszej kolumnie jest opisane zbawcze zdarzenie a ¡i następnych trzy jego typy. Górna część kolunmy często jest zajęta przez miniaturę. Pierwsze dwa rozdziały są poświęcone początkom świata i człowieka do Noego, następne $(3-6)$ życiu Marii, a rozdziały 7 do 42 są chrystologiczne. Czasem na końcu są dołączone mistyczne rozprawki o 7 ranach Pana Jezusa, 7 boleściach Matki Boskiej i o 7 Jej radościach. Z czasów średniowiecznych zachowało się około 250 rękopisów Speculum. Por. P. Perdrizet, Etude sur le Speculum humanae salvationis, Paris 1908.

20 ,Filia Jephte oblata est pro victoria hostium temporalium, per Mariam facta est victoria hostium infernalium" (Speculum humanae salvationis, V 35-54). 
trójarkadowej loggi królewskiego oratorium Marii widzimy na pierwszyri planie ogród, a za jego murem niezmierzony widok słonecznej okolicy z płynącą pośrodku rzeką. Niżej od kaplicy położony ogród obfituje w róże, lilie i irysy. Officium o Wniebowzięciu powtarza: „Et sicut dies verni circumdabant eam flores rosarum et lilia convalium". Kwiaty w ogrodzie mają symbolikę maryjną, przypominającą rajski hortus conclusus. Ogródek kwiatowy kończy się niskim murem blankowym, przez który wyglądają na rzekę dwie małe, tyłem obrócone postacie ${ }^{21}$.

Przez triadę jasnych otworów widać — jak wyżej wspomniano rzekę, nad którą jest przerzucony most, wsparty na 7 arkadach. Zwyczajem średniowiecznym na moście postawiono krzyż — znak Zbawienia. Za mostem, na tle błyszczących wód, odbija się zarys wyspy z obwarowanym zamkiem. Po rzece, która dalej kręci się zakosami, pływają łodzie. Ogląd terenu jest bardzo szeroki, bo Eyck zaznacza nawet najodleglejsze przedmioty. Na horyzoncie sinieją góry pokryte wiecznym śniegiem. W ogóle można powiedzieć, że krajobraz jest natchniony przez doline Mozy, ale w zasadzie fantazyjny ${ }^{22}$. Na lewym brzegu rzeki widać częśc miasta z kościołem i budynkiem klasztornym, a na prawym główne miasto $z$ katedrą i z innymi licznymi kościołami. Katedra przypomina ksztalt kościoła św. Guduli z Brukseli. Wieżyczka obok główki Dzieciątka jest kopią z kościoła św. Marcina w Utrechcie ${ }^{23}$.

Można przypuszczać, że obraz Madonny z Autun z kanclerzem Rolinem powstał jako votum za zawarcie pokoju między Burgundią a Francją Karola VII, po zerwaniu sojuszu z Anglią. Albowiem Filip Dobry w 16 lat po gwałtownej śmierci swego ojca darował zabójcy, królowi

21 Różne sa próby wyjaśnienia, kogo przedstawiaja owe dwie figurki przy murze. Jean Lejeune (Les van Eyck, peintres de Liège et sa cathedrale, Liège 1956, 200-205) uważa, że sa to dwaj malarze: Hubert i Jan van Eyck, Kępiński natomiast (Madonna kanclerza Rolin, 153 n.) jest zdania, że to książę Filip Dobry ze swoim kanclerzem.

${ }_{22}$ Malując idealny obraz miasta, artysta świadomie przenosi nas w świat zaziemski, posługując się bogatą symboliką przedstawień. Charles de Tolnay tak tę sprawę ujmuje: „Sans se detacher de contigeances de la nature, il suspend la durée et cree un monde à la fois reel et imperissable ... On comprend alors l'eclat surnaturel, qui dans cette oeuvre enveloppe tous les objects. Les passions sont eteintes dans cet univers immuable ou les hommes, detaches des soucis, ,participent à la beatitude qui émane des choses" (Le Maitre de Flemalle, 30). Obraz ogrodu i miasta Bożego, szczególnie rzekę wypływającą spod fundamentów niebieskiego Jeruzalem, wywodzi Kępiński z rozdziałów 40-42 i 47 proroctwa Ezechiela (Madonna kanclerza Rolin, 114-116, 119 n.). Róże, lilie i kosaćce są związane z kultem Marii. Paw symbol nieśmiertelności, jest antycznym wyrazem konsekracji królowej, w tym wypadku królowej nieba Marii (K. Lothar, Der Pfau in der altchristlichen Kunst, Leipzig 1939).

${ }_{23}$ Dokładny obraz wieży katedry w Utrechcie posiada również główna częś Adoracja Baranka. Pa n of sk y (Early Painting, 225) sądzi, że tę wieżę, widniejącą na horyzoncie krajobrazu Adoracji z osmiobocznym przéroczem, domalował w polowie XVI wieku renowator Jan Scorel z Utrechtu. Ta supozycja nie jest konieczna, bo Jan Eyck podobnym tłem widnokręgu posłużyl się w Madonnie $z$ Autun. Por. Z. Kępiński, jw., s. 127 , ryc. 31. 
francuskiemu, i zawarł $\mathrm{z}$ nim (21 IX 1433) traktat pokojowy w Arras, walnie przyczyniając się do rychłego zakonczenia wojny stuletniej, prowadzonej między Anglią a Francją. Uzyskawszy ten sukces polityczny, kanclerz burgundzki chciał okazać wdzięczność patronce swego kościoła w Autun. Toteż niedługo po r. 1435 złożył w kaplicy rodowej cenny dar wotywny, w postaci obrazu Jana v. Eycka, przedstawiający jego hołd dla Królowej niebios ${ }^{24}$.

\section{Salve, Mater Misericordiae}

(Portret z r. 1436 kanonika Jerzego van der Paele)

Wśród duchowieństwa w Brugii posiadal Jan van Eyck przyjaciela w osobie Jerzego van der Paele’a, kanonika kościoła św. Donacjana W kolegiacie poświęconej temu świętemu, umęczonemu za czasów Dinklecjana w Nantes, Eyck chciał po śmierci spoczywać. Na prośbę kanonika Eyck wymalował obraz wotywny ku czci N. Marii Panny i świętych patronów (Jerzego i Donacjana). Płótno to miało być złożone w kolegiacie z prośbą o zdrowie dla donatora.

W obrazie tym Eyck przedstawił wnętrze romańskiego prezbiterium, otoczonego ambitem, widocznym poprzez przeźrocza arkad. W miejscı ołtarza jest ustawiony tron $\mathrm{z}$ baldachimem, na którym zasiadła Maria $\mathrm{z}$ nagim Dzieciątkiem na prawym kolanie. Dziecię siedzące frontalnie obraca się ku Matce. Maria prawą ręką podtrzymuje Syna, a lewą podaje mu bukiet kwiatów. Mały Jezus zabawia się papużką ${ }^{25}$. Na stopniach tronu i środkiem prezbiterium biegnie od stóp Matki Boskiej wzorzysty dywan. Tronującej w czerwonym płaszczu asystują po obu stronach dwaj święci. Na lewo stoi w pontyfikalnym stroju biskup Donacjan. trzymający w jednej ręce kosztowny krzyż ${ }^{26}$, w drugiej — świecznik w kształcie korony, z czterema zapalonymi świecami (piąta zgaszona). Patron kościoła nałożył na głowę infułę wysadzaną drogimi kamieniami, a na ramiona narzucił bogatą wzorzystą kapę. Po prawej stronie staną w pełnej zbroi św. Jerzy, patron kanonika. Spod żelaza widoczne są tylko ręce i twarz świętego, który przed Matką Boską zdejmuje wielki rycerski kapelusz, a lewym łokciem podtrzymuje proporzec, dłoń opierając

24 Porównaj również rozprawy odnoszace się do Eyckowej Madonny z kanclerzem Rolin: Baldass, Jan van Eyck, London-New York 1952, 58 n.; E. Panofsky, Rzeczywistość i symbol, 131 n. ryc. 133; H. Roosen-Runge, Die Rolin Madonna des Jan van Eyck, Wiesbaden 1972.

25 H. Beenken, Hubert und Jan van Eyck, München 1941, 66-67.

26 Doradca Jana van Eycka przy malowaniu złotniczych przedmiotów mógł byé Jan Leeuw, złotnik brugijski, któremu równocześnie z obrazem palowym (1326) wykonał portret, znajdujący się obecnie w Kunsthistorisches Museum w Wiednitu. Zlotnik patrzący $z$ płótna mocno i stanowczo, trzyma $w$ palcach znak swego zawodu - złoty pierścień. Na starej ramie napis z chronogramem. Por. A. Dohmann, Die altniederländische Malerei, 32 . 
ruchem wskazującym o pierś kanonika. Jerzy van der Paele klęczy na stopniu oltarza przed swoim patronem, który bierze go w swoją protekcję. Kanonik, ubrany w białą kamizję, na lewej ręce zawiesił popielice, które są oznaką jego kolegiackiej godności, dłońmi zaś podtrzymuje książeczkę do modlitwy. Palcami prawej ręki przewraca karty z nabożnym tekstem, trzymając okulary w czarnej oprawie. Pod oprawę książki kanonik podkłada złożoną częściowo torebkę ze świńskiej skóry, która mu sỉużyła do przechowywania cennego kodeksu. Oblicze kanonika jest namalowane z najwyższym realizmem, co szczególnie zwraca uwagę w zestawieniu $\mathrm{z}$ idealistycznymi twarzami reszty postaci. Charakterystyka fizycznych cech Jerzego jest tak daleko posunięta, że malarz dokładnie oddał każdą zmarszczkę, każdy włosek na twarzy. Twarz kanonika zdradza starość i chorobę.

Jerzy van der Paele czuje się w obliczu tronu Bogarodzicy onieśmielony. Przewraca karty $w$ księdze modlitw, ale nie odważa się popatrzeć w stronę Matki Miłosierdzia, choć przyszedł tu po to, aby u Niej szukać przywrócenia zdrowia, otuchy i pociechy $w$ chorobie. Twarz jego jest bardzo poważna, bo Jerzy zwraca się do Marii, jako biedny potomek Ewy, zamieszkały na łez padole. W swej niegodności ucieka się o pomoc do dwu swych patronów: jeden z nich arcykapłan, drugi - rycerz. Elementy symboliczne na gotyckich kapitelach podkreślają tę podwójną rolę przewodników kanonika w nadprzyrodzonym świecie. Po stronie św. Donacjana wyrzeźbione są dwie sceny: Spotkanie Abrahama z Melchizedechem i Ofiara Abrahama, odnoszą się do biskupiej władzy składania Bogu ofiar. Na prawo, po stronie św. Jerzego, widzimy wojny święte Starego Testamentu, przede wszystkim walka Dawida z Goliatem, a więc motyw rycerski.

Na cparciach tronu Matki Boskiej, w niszach na przedzie słupka, widoczne są postacie obojga pierwszych rodziców. Na lewo nad Ewą postawiona jest na poręczy grupa rzeźbiarska Kaina zabijającego Abla, a na prawo ponad Adamem figura Samsona rozdzierającego lwa. Oba przedstawienia są obrazem padołu płaczu, na którym znajduje się schorowany i słaby kanonik. Życzliwa pomoc patronów, zwłaszcza św. Jerzego, wskazującego na kanonika ukłonem składanym kopiastym hełmem, wyjednala te laskę, że łaskawa Panna Maria swą łagodna twarz i oczy obróciła na Paele'a. Nawet Dziecię Jezus zaprzestało zabawy z papużką i z uśmiechem patrzy na smutną twarz chorego kapłana ${ }^{27}$.

Z mistrzostwem rozwiązuje Eyck problem światła w tym obrazie Wpada ono do wnętrza prezbiterium z kierunku północnego przez go-

$\because$ E. Panofsky, Early Painting, 183; tenże, Rzeczywistość i symbol, s. 132 , ryc. $135 ; \mathrm{H}$. Beenken, Hubert, 69; Ch. de Tolnay, Le Maitre de Flemalle, 32 . 
mółkowe szybki w ambicie. Najbliższym jednak źródłem światła są zapalone świece, trzymane przez św. Donacjana; sprawiają one niezwykłe refleksy świetlne i barwne. Czerwony płaszcz odbija się w krzyżu Donacjanowym, jak również na gładkiej powierzchni zbroi św. Jerzego, na której i cień samego artysty może się rysuje.

Kanonik Paele przeżył Eycka tylko o dwa lata. W kolegiackim kościele św. Donacjana zawisł obraz, który był nie tylko darem wotywnym Jerzego Paele'a, lecz również pomnikiem spoczywającego w tymże samym kościele malarza. Chwałę fundatora i wykonawcy głosił napis na obrazie: „Hoc opus fieri fecit magister Georgius de Pala, huius ecclesiae canonicus, per Johannem de Eyck pictorem. Completum anno 1436". Niestety obraz $z$ kościoła zabrano i przeniesiono do Muzeum $w$ Brugii (Musee Communal).

\section{Maria Gwiazdą Zaranną wędrowca}

(Drezdeński tryptyk podróżny z r. 1437)

W r. 1436 książę Filip Dobry zlecił Eyckowi sekretną misję, prawdopodobnie na południe do Włoch. Przypuszcza się, że podczas tego pobytu Eycka w Italii tamtejszy nobile z rodziny weneckiej Michaele Giustiniani zamówił u sławnego artysty mały tryptyczek (otwarty liczył $40 \mathrm{~cm}$ szerokości), do odprawiania nabożeństw w czasie podróży. Po zamknięciu skrzydeł mógł on, z uwagi na swe niewielkie rozmiary, z łatwością byc przewożony w tobołach i kufrach, szczególnie w czasie dalekich podróży. Data 1437, zapisana na ramie, została odnaleziona w czasie oczyszczania tryptyku w r. $1960^{28}$. Obecnie to niewielkie, ale pełne uroku dzieło niderlandzkiego malarza znajduje się w galerii malarstwa (Die Gemäldegalerie) obok Zwingeru w Dreźnie.

Srodkowa deska tryptyku przedstawia romańską nawe kościelna. Biegnące krajem kolorowe kolumny, z których każda zwyczajem rzymskiego antyku posiada osobny wysoki styloblat, lecz romańskie, ze wzorem roślinnym kapitele dźwigające okrągłe archiwolty, wskazują, że do navy głównej przylegają boczne. Miejsce oltarza zajmuje tron Marii z zielonym zapleckiem i takimże baldachimem zdobnym kwiatami. $\mathrm{Na}$ tronie siedzi Maria obleczona czerwonym płaszczem, z wieńcem pereł na odkrytej głowie i oboma ramionami podtrzymuje nagie Dzieciątko, usadowione okrakiem na Jej prawym kolanie. Maly Jezus zwrócony do nas frontalnie podnosi rączki. Na prawą Jego piąstkę narzucony jest koniec banderoli, spadającej w dół, przez którą biegnie trudny do odczytania napis. Posadzka całej nawy głównej wysłana jest różnokolorowymi dywanami. 
Boczne skrzydla drezdeńskiego tryptyku poszerzają przestrzeń kościelną, bo na nich są wymalowane wnętrza naw bocznych. Na lewym skrzydle widzimy fundatora, który wszedł do kościoła przez otwarte od północy drzwi i uklęknął w obliczu Matki Boskiej, protegowany przez stojącego za nim patrona - św. Michała Archanioła. Książę wojsk niebieskich obleczony jest w pełną zbroję, jednakże z głowy zdjął z uszanowaniem szyszak i podtrzymuje go odsłoniętą lewą dłonią, a prawą, również nie uzbrojoną, dotyka ramienia klęczącego oranta, który, nie wiadomo dlaczego, nie zdjął beretu z głowy. Długą dzidę — swój emblemat -oparł Archanioł Michał o siebie, zaś do góry podnosi mieniące się kolorami tęczy skrzydła - oznakę godności anielskiej.

$\mathrm{Na}$ prawym skrzydle zatrzymała się ubrana w niebieską suknię św. Katarzyna. Oczy jej zwrócone są na tekst otwartej księgi, trzymanej w lewej ręce. Prawą obejmuje miecz, oparty ostrzem o posadzkę. Panieńska patronka filozofów nosi na spuszczonych w kierunku ramion włosach złocistą koronę, mimo że sama Matka Boska w tym tryptyku jej nie posiada. Według ówczesnego ideału piękności kobiecej św. Katarzyna jest przedstawiona jako ciężarna.

Właściciel tryptyczka otwierając go cieszył się widokiem Bogarodzicy i Dzieciątka, zwracając swe oczy na jego podobiznę, umieszczoną na lewym skrzydle. Jezus poddaje mu słowa modlitwy wypisane na banderoli. Ponad tronem Matki Boskiej trzy okna malowane w kolorowe wzory sa rozjaśnione światłem od wschodu. Ta triada wyraża Trójcę świętą, która Swą opatrznością czuwa nad całym światem. Swiatło bijące przez północną bramę oświetla dolną część kościoła, podczas gdy góna tonie w cieniu. Widać jednak postacie apostołów, stojące między archiwoltami nawy na gotyckich konsolach, nakryte daszkami wybiegajacymi w sterczyny znaczone żabkami, zakończone kwiatonami. Swiatło powstające od wschodu widać szczególnie na prawym skrzydle, gdzie fundator, kochający się w studiach dialektyki, cieszył się obrazem patronki filozofów.

$\mathrm{Na}$ kapitelach obok tronu Matki Boskiej sceny z Księgi Rodzaju, z dziejów rajskich i Abrahama, mówiące o słabości człowieka, a usposabiające do pokornej modlitwy. Ponad Archaniołem Michałem sceny z walk narodu wybranego. Na zewnętrznej stronie skrzydeł tryptykı pojawia się Zwiastowanie, podobnie jak w tryptyku gandawskim, wykonane en grisaille. W dwu niszach stoją na wielobocznych gotyckich podstawach posągi: na lewo anioł, na prawo Najświętsza Maria Panna. 


\section{Madonna przy fontannie wody żywej.}

(Obraz z r. 1439)

Ostatni obraz maryjny, namalowany przez Eycka na dwa lata przed śmiercią, posiada wiele symbolizmu, związanego ze schyłkiem życia malarza. Jest to Madonna przy fontannie (Musée Royal d'Anvers). Niewielkie rozmiary obrazka $(19 \times 12,5 \mathrm{~cm})$ sprawiają, że postać Marii z Dzie-ciątkiem wydaje się wielka. Napis potwierdza autorstwo: „Johannes de Eyck me fecit et complevit anno 1439".

$\mathrm{Na}$ tle ogrodu, podniesionego na podmurówce z 4 warstw ciosanych kamieni i zamkniętego różanym żywopłotem, stoi Matka z igrającym Dzieckiem na ręku. Oparta jest o niezbyt szeroką czerwonozłotą makate brokatową, trzymaną przez dwóch aniołów u góry, na dole zaś układającą się gładko pod Jej stopami. Podczas gdy aniołowie występują w szatach zaróżowionych, a Dzieciątko jest prawie nagie, Maria jest okryta niebieskim płaszczem. Ten, jak wiemy, na innych malowidłach był zastepowany przez czerwień draperii. Włosy Marii nie spływają z głowy na sposób panieński, lecz są spięte z tyłu, nad czołem zaś okala je wieniec z paciorków. Występuje tu jako czuła Matka bez baldachimu, bez oznak królewskich. Dzieciątko tuli się do Matki, prawą rączką obejmują Ją za szyję, a twarzyczkę zbliża do policzka Piastunki: jest to wzór bizantyńskiej Eleusy, czyli ruskiego Umilenia. Odrzuconą lewą rączką Pan Jezus trzyma sznur paciorków. Szczegół ten, jak i ogród z kwitnącymi różami widniejący za Marią (,hortus conclusus”), wskazuje na charakter różańcowy obrazu. Z tego względu Matka Boska stanęła nie na tle - jak bywało dawniej - architektury kościelnej, ale na tle nastrajającego do modlitwy i pociągającego pięknością ogrodu ${ }^{29}$.

Wokół Marii ścieli się kwiecista ława darniowa, w niej na przedzie po lewej stronie wydrążone zostało zagłębienie cembrowane i w nim ustawiona miedziana studzienka. Ma ona kształt wysokiego słupa metalowego. Na jego szczycie umieszczona jest kula z siedzącym na niej lwem, a z kuli spływa woda do niżej przytwierdzonej misy. Jan miał upodobanie w przedstawianiu podobnych prac miedziowników. Za nim powtarzali ten motyw malarze flamandzcy i inni, pozostający pod ich wpływem. Fontanna ta wyraża symboliczne źródło życia ${ }^{30}$.

Ostatni obraz maryjny Eycka ma nastrój liryczny. Do Marii, zwyczajnej matki, bez oznak królewskich, owszem wyglądającej na kobiete z ludu, ucieka się z wielkim uczuciem Jej Dziecię; artysta chce wyrazić swą wielką ufność do Matki niebieskiej, w obliczu uciekającego życia.

29 E. P a n ofsky, jw., 186. (1953).

O. Kerber, Jan von Eyck's Madonna am Brunnen, „Das Münster” 6 
Może był chory i w obrazie błaga Matkę Różańcową i Matkę milosierdzia o zdrowie, prosi o użyczenie mu żywej wody, która by go pokrzepiła i przywróciła mu siły, wyrażone na obrazie przez lwa, siedzącego na gałce fontanny. To ostatnie wołanie do najlepszej Matki zostawił Eyck jako swój testament i pożegnanie $\mathrm{z}$ ziemskim życiem ${ }^{31}$.

\section{MONOCHROMICZNY OBRAZ ŚW. BARBARY (r. 1437)}

W muzeum antwerpskim (Musée Royal d'Anvers) znajduje się mała tabliczka, wysoka na $35 \mathrm{~cm}$, pokryta szarą farbą na kredowym tle. Ten jednobarwny obraz przedstawia św. Barbare, męczennicę nikomedyjską z czasów cesarza Maksymina Dai (ok. 306). Mimo braku koloru, niewielkie dzieło Eycka cieszy oczy mistrzowską formą i kompozycją. Niektórzy badacze twierdzą, że obrazek jest niewykończony i daje nam znakomity pogląd na sposób tworzenia niderlandzkiego artysty. Ten najpierw pokrywał deskę pokładem kredowym, a potem na to nanosił dokładny rysunek pędzlem, tak że położenie farby na powierzchni gruntu było tylko wtórną okolicznością. Otóż na omawianym obrazku Eyck począł pokrywać farbą obszar nieba, ale reszty nie wykonał. Innego zdania jest słynny historyk sztuki Erwin Panofsky ${ }^{32}$. Uważa on, że w intencji Jant Eycka obraz miał pozostać in statu praeparationis; świadczy o tym subtelne wykonanie włosów św. Barbary, które u artystów flamandzkich bywało na przygotowanym do malowania gruncie ogólnikowe. Gdyby to nie było zamknięte i skończone dzieło, a tylko przygotowane do położenia barw, to by Eyck na dole marmoryzowanej ramy nie położył napisu: „Johannes de Eyck me fecit 1437". Taki szkicowy stan obrazu, stanowiącego przedmiot estetycznego oglądu, jest w średniowieczu jedynym i bezprzykładnym faktem.

Sw. Barbara siedzi na wzgórzu. Kraj płaszcza świętej spływa n’x przednią stronę wzniesieni, zakrywając je licznymi ufałdowaniami. Ich rozległość stanowi kontrast do wiotkiej kibici dziewczęcia. Głowa panny, z włosami spadającymi po obu skroniach, nie posiada żadnych ozdób. Na szyi widać skromny wieniec bursztynów. Oczy męczenniczki spuszczone są na leżącą na jej kolanach księgę Pisma Świętego. Iluminowane karty przewraca palcami prawej ręki, podczas gdy w lewej trzyma znak swego męczeństwa - długą gałąź palmy.

$31 \mathrm{Na}$ pożegnanie z żoną przed śmiercią wykonal jej portret (1439), zachowany w Musée Communal w Brugii. Eyck nie starał się upiększać rysów swej małżonki; przedstawił z całym realizmem twarz przedwcześnie starzejącej się kobiety, mającej zaledwie 33 lata. Na ramie portretu widnieje sygnaturka: "Coniunx meus Johannes me complevit anno 143917 iunii. Aetas mea trigninta trium annorum. Als ick kan." Por. A. Burroughs, Jan van Eycks Portrait if his Wife, w: Melanges Hulin de Loo, (b. m.) 1931, 66; E. Panof s ky, jw., 195.

32 E. Pan of s ky, jw., $185 \mathrm{n}$. 
Za pogórkiem, na którym siedzi św. Barbara, wznosi się potężny masyw gotyckiej wieży, wybudowanej tylko do wysokości pierwszego piętra. Wieża ta stanowi indywidualny atrybut świętej ${ }^{33}$, lecz artysta potraktował budowlę nie tylko jako symbol hagiograficzny, ale także jako równo-rzędny z nią przedmiot. Van Eyck miał przy tym okazję zapisać swym pęalem cenne szczegóły do dziejów sztuki architektonicznej w średniowieczu i do organizacji budownictwa kościelnego. Na placu budowy krzątają się liczni pracownicy, poznajemy, jak się odbywa transport materiałów, jak pracują murarze i kamieniarze na dole i na górze masywu budowlanego. Spostrzegamy też odwiedziny jakiejś dostojnej inspekcji. Do wieży przylega szopa budowlana, gromadząca zorganizowanych przy budowie członków słynnych średniowiecznych korporacji (Bauhütte). Tam przechowywali oni narzędzia, spożywali posiłki i odpoczywali w czasie poobiedniego skwaru słonecznego, a w czasie niepogody i zimowej pory przygotowywali rzeźbione elementy budowy. Szopy te, jako centrum życia organizacyjnego, miały być - jak się przypuszcza - zaczątkiem przyszłej masonerii. Dormitoria dla murarzy i kamieniarzy były budowane osobno ${ }^{34}$. Całe to pole budowy opływa za wieżą w półkole rzeka.

Wznoszona wieża jest prócz tego symbolem szczególnej idei budowania królestwa Bożego na ziemi. Wieczorny hymn na święto Poświęcenia kościoła powiada:

„Coelestis urbs Jerusalem,
Beata pacis visio,
Quae celsa de viventibus
Saxis ad astra tolleris...
Scalpri salubris ictibus
Et tunsione plurima,
Fabri pollita malleo
Hanc saxa molem construunt,
Aptisque iuncta nexibus
Locantur in fastigio".

Już św. Paweł (Ef 2, 19-20) głosił pogląd, że Kościół jest budowlą, stawianą na fundamencie apostołów i proroków, której kamieniem węgielnym jest Chrystus. W szczególny jednak sposób wyraził to w połowie II wieku Hermas, podobno brat papieża św. Piusa I, w swym dziele, zatytułowanym Pasterz. W wizji III ukazała mu się matrona, która kazała mu usiąść obok siebie i wskazała na murowaną wieżę, mówiąc: „Czy nie

33 Motyw wieży, jako symbol panieńskiej czystości, pochodzi z antycznego mitu - Danae, córce Eurydyki i Akrisjosa, króla Argos. Ojciec otrzymawszy przepowiednię, że syn córki go zabije, zamknął Danae w niedostępnej wieży, by nie miała kontaktu z ludźmi. Ten wątek odpowiednio przekształcony, dostał się do legendy św. Barbary.

${ }_{34}$ J. Gimpe 1, Jak budowano $w$ średniowieczu, Warszawa 1968, 93-95; B. Zientara, Historia pouszechna średiniowiecza, Warszawa 1968, 201 (podobizna miniatury Jana Fouqueta wykonanej dla Starożytności żydowskich Józefa Flawiusza, przedstawiającej budowę katedry w Bourges). 
widzisz przed sobą potężnej wieży, jak wznosi się nad wodami, budowana z lśniących czworobocznych kamieni? ...Otóż wieża, na której budowanie patrzysz, to ja, Kościół, który ci się zjawił... Wieża wznosi się nad wodami, ponieważ życie wasze zostało i będzie zbawione przez wodę... Młodzieńcy budujący wieżę, to święci aniołowie Boży, a kamieniami są wierni" 35 .

$\mathrm{Na}$ obrazie Eycka za wieżą rozciągają się pagórki, pokryte lasami, a na lewo na górze zamek, miasto Boże. Podobnie do Hermasa, Jan Eyck pod patronatem św. Barbary, pokornej dziewicy, siedzącej z księgą Objawienia Bożego na ziemi (Panofsky nazywa ją ,,Virgo Humilitatis'), rozmyśla o swym obowiązku budowania królestwa Bożego na ziemi. Pod wpływen: wieści o nadmiarze nieszczęść spowodowanych wojną stuleinia, w sercu Van Eycka ożywiły się uczucia religijne; malarz pragnie, by tak w jego sercu, jak i w sercach wyznających Chrystusa wzrastało ukochanie rzeczy Bożych i wieży-Kościoła, bo, jak mówi Pasterz Hermasa, ,podwaline wieży stanowi Imię Wszechmocne i pełne chwały; a siłą podtrzymująca wieżę jest niewidzialna moc Pańska". W obrazie Eycka występuje połączenie medytacji duchowej z naturalistyczną wizją szopy kamieniarskiej w pełni akcji budowlanej ${ }^{36}$.

\section{PORTRET MA£ŻONKOW ARNOLFINICH}

Zdaje się, że wśród mieszczaństwa brugijskiego najbliższym przyja-cielem Van Eycka był kupiec przybyły około r. 1420 z Lukki do Brugii i tu na stałe osiadły, nazwiskiem Giovanni Arnolfini. Książę Filip Dobry poznał się szybko na niezwykłych zdolnościach Włocha jako biegłego finansisty, nobilitował go i uczynił go swym ,,valet de la chambre" ${ }^{37}$. Dla tego Jana Arnolfiniego Eyck wykonał najpierw pojedynczy portret, zachowany w Berlinie-Dahlem, ale największe zainteresowanie wywołuje podwójny wizerunek samego Jana i jego żony Giovanny Cenami, córki włoskiego kupca z Paryża, wykonany z okazji ich ślubu w r. $1434{ }^{38}$.

Ten zdumiewający pięknością podwójny portret stoi na granicy rodzajowości i malarstwa portretowego. Jest to pierwszy portret, który dosięgnął takich wyżyn sztuki, stanowiący intymną scenę we wnętrzu

35. M. Michalski, Antologia literatury patrystycznej. I 1, Warszawa 1969, $49-51$. 221.

R. Genaille, Dictionaire des peintres flamands et hollandais, Paris 1967,

3i H. B e e n ke n, Hubert und Jan van Eyck, München 1941, 54.

38 M. W. Brockwell (The Pseudo-Arnolfini-Portrait: A Case of mistaken identifyt, London 1952) uważa, że to jest portret samego malarza Jana Eycka i jego żony Małgorzaty. Por. również: Z. K ęp iński, Jan Van Eyck: "Małżeństwo Arnolfinich" czy „Dawid i Betsabea”, ,Rocznik Historii Sztuki” 10 (1974), $119-164$. 
mieszczańskiego domu, a zarazem symbol sakramentu małżeństwa, pochwałę wierności małżeńskiej i poemat wzajemnego zaufania i szczęścia. Pod względem wartości malarskich jest on w twórczości Eycka wprost wyjątkowy. Eyck w tym arcydziele portretowym doszedł do szczytów formy i harmonii, sposobów ustawienia osób w przestrzeni, użycia światła i koloru, których już sam nigdy nie przewyższył ${ }^{39}$.

Oboje nowożeńcy Arnolfini, ubrani według mody burgundzkiej (mężczyzn obowiązywał wtedy wielki kapelusz), stoją w nieznacznej odległości od siebie. Lekko ku sobie obróceni nie patrzą na siebie, ale się czuja zjednoczeni w tej doniosłej chwili związkiem wielkiej tajemnicy. Uroczysty charakter tej ceremonii jest podkreślony przez symetrię kompozycji, zawieszenie w górze na środku żyrandola i lustra konweksowego na ścianie. Na podłodze leży mały piesek griffon-terrier.

Jest to obraz zawarcia sakramentu małżeństwa. W średniowieczu konsens matrymonialny składano najczęściej w mieszkaniu. Małżeństwo zawierano przez złożenie przysięgi (fides - iuramentum), na którą składały się przy wymawianiu słów dwie akcje: fides manualis czyli złączenie rąk, a ze strony nowożeńca dochodziło podniesienie ramienia (fides levata). Przed Soborem Trydenckim (1563) możliwe były tak zwane ,matrimonia clandestina", zawierane w domu, a zawierajacy małżeństwo udawali się do kościoła już jako małżonkowie ${ }^{40}$, aby odebrać błogosławieństwo od kapłana. Dopiero Sobór Trydencki wprowadził zasadę, że ma1żeństwo wtedy będzie ważnie zawarte, gdy konsens będzie złożony „coram parocho" (który był testis qualificatus) ,et duobus aliis testibus”.

Portret ten przedstawia także wiele elementów symbolicznych. Fakt uroczystego zawarcia małżeństwa podkreśla paląca się przy jasnym dniu jedna świeca w mosiężnym żyrandolu. Jest ona symbolem wszystkowidzącego Chrystusa. Swieca ta (die Brautkerze, the marriage candle) była niesiona do kościoła przed orszakiem weselnym, gdy małżonkowie udawali się w myśl przykazania kościelnego do kapłana, aby otrzymać od niego błogosławieństwo, a także płonęła w domu w czasie uczty weseinej. W mieszkaniu widocznym na obrazie zauważamy zawieszone na ścianie duże lustro wypukłe, speculum sine macula, otoczone 10 medalionami ze scenami pasyjnymi. Wyraża ono czystość chrześcijańskiego małżeństwa. Stojący między małżonkami na podłodze pies jest starodawnym symbolem wierności. Pojawia się on często na nagrobkach, zwłaszcza

39 E. Panofsky, Jan van Eyck an Arnolfini Portrait, ,The Burlington Magazine" 64 (1934), 117 n.; t e nż e, Early Painting, 202 n.

40 Św. Tomasz z Akwinu, Summa Theologiae III, q. 46, art. 2: „Secundum iudicium Ecclesiae carnalis copula consequens sponsalia matrimonium facere iudicatur": tamże q. 42, art. 1: ,Ad primum ergo dicendum, quod verba quibus consensus exprimitur matrimonialis, sunt forma huius sacramenti, non autem benedicto sacerdotis, quae est quoddam sacramentale". 
pod stopami kobiet, w celu wyrażenia cnoty wierności małżeńskiej, która się zmarła za życia odznaczała. Jabłka, leżące na ławie okiennej, były symbolem wzajemnej miłości, stąd istniał zwyczaj, że narzeczeni przed zawarciem ślubu dzielili się jabłkiem. Symbol ten często powraca w pieśniach weselnych, co wydaje się echem opowiadania o dziejach rajskich. Ponadto dziwnym się może wydawać, że Giovanni tak uroczyście do ślubu się przyodziawszy, zrzucił buty. Jest to symbolem świętości małżeństwa. Tu trzeba się odnieść do 3 rozdziału Księgi Wyjścia (w. 5), mianowicie do słów Bożych, zwróconych do Mojżesza: „Zzuj obuwie z nóg twoich: miejsce bowiem, na którym stoisz, ziemia święta jest".

Obraz Van Eycka jest nie tylko podwójnym portretem, wyobrażeniem ceremonii ślubnej, ale także metryką ślubu. Ponad lustrem, wiszącym w głębi na ścianie, czytamy napis: „Johannes de Eyck fuit hic 1434". Jest to nie tylko podpis artysty, który wykonał dzieło, ale także podpis świadka ślubu. W zwierciadle odbija się ta część pokoju sypialnego, której nie widać na obrazie, a oboje małżonkowie są widziani od tyłu. W głębi natomiast odbiły się drzwi wiodące do komnaty, i w ich progu postacie dwóch mężczyzn: jest to Jan Eyck z towarzyszem; zaproszeni do wzięcia udziału w obchodzie ślubnym.

Przy końcu warto wspomnieć na uwagę Panofsky'ego, że naturalizm sztuki niderlandzkiej bynajmniej nie był zeświecczeniem sztuki. Artyści byli przekonani, że rzeczy fizyczne są metaforą rzeczy duchowych. Tak się dokonywała widoczna w średniowieczu sanktyfikacja świata widzialnego, zacierająca granicę między tym, co „sacrum” a co „prophanum" 41.

Jan van Eyck umarł w Brugii krótko przed 9 lipca 1441. Jego przyjaciel, kanonik Jerzy van der Paele, złożył zwłoki artysty w kościele św. Donacjana; fakt ten zapisano w Obituarium tejże kolegiaty. Wdowa po malarzu otrzymała od księcia Filipa Dobrego 600 funtów gratyfikacji, co świadczy o wielkim uznaniu władcy dla zmarłego Jana. Ten wielki mistrz malarstwa wykazał w swej genialnej twórczości wszechstronne wykształcenie w wielu dziedzinach ówczesnej wiedzy. Choć wbrew dotychczasowym opiniom nie był wynalazcą malarstwa olejnego, to jednak on wprowadził nowe środki wyrazu do tego malarstwa i nowy sposób oddawania rzeczywistości w słońcu, powietrzu, w prześwietlaniu barw, oddawaniı subtelnych efektów świetlnych. Nie był pierwszym malarzem flamand7kim, ale zdobycze swych poprzedników, takich braci Limburg, ilumina.torów wspaniałego kodeksu Les tres riches Heures du duc de Berry, lub

41 E. Panofsky, Early Painting, 142. 
iluminatora marszałka Boucicaut, wreszcie rzeźbiarza Clausa Slutera, potrafił podnieść do nieosiągalnych dotychczas wyżyn.

Lecz nade wszystko Jan van Eyck był malarzem religijnym. Przedstawiał on wizję prawd chrześcijańskich, umiał łączyć świat niebieski z życiem ziemskim, świat duchowy $z$ życiem materialnym. I to jest szczególne u Eycka, że porządek niebieski i życie ludzi na ziemi splatają się w najbardziej naturalny i prosty sposób. Nikt dotąd nie potrafił tak realistycznie przedstawiać rzeczywistości, jak to czynił Eyck. Jednakże nowe odkrycia w ujmowaniu prawdy otaczającego nas świata nie oddalają go od religijnego światopoglądu. Im lepiej poznaje świat, tym głębiej wiąże go $z$ myślą teologiczną. Posługując się ziemskimi przedmiotami w symbolice, przybliża niebo ku ziemi. Wykonując z mistrzowską biegłością realistyczne szczegóły w religijnych obrazach i dając nam obraz związany z tym światem, w gruncie rzeczy stwarza nastrój idealistyczny, zaciera granicę między prophanum a sacrum. Najpotężniejszym hymnem czci chrześcijańskiej myśli teologicznej w malarskiej twórczości Van Eycka jest Tryptyk Gandawski ${ }^{42}$.

42 Por. B. Przybyszewski, Adoracja Baranka, „Analecta Cracoviensia” 8 (1976), $365 \mathrm{nn}$.

JEAN VAN EYCK EN QUALITÉ DE PEINTRE RELIGIEUX ET DE PORTAITISTE

\section{RES U M E}

De l'atelier de Jean van Eyck provenaient les peintures qui glorifiaient particulièrement Sainte Vierge et aussi quelques portraits, dont les traits ont été rendus avec réelisme très avancé:

Les premiers oeuvres représentaient Marie sur le fond d'une église (1428). C'est tableau de Berlin et celui de l'Annonciation de Washington, qui se déroule sur le fond de la magnifique architecture d'une cathédrale. Marie est le miroir de la perfection de l'église et sa représentation.

Dans le triptique de Grand (1432) et les deux suivants van Eyck introduit Marie dans un intérieur bourgeois. Dans celui de tableau de Melbourne (Ince Hall Madonna) Marie montre à l'Énfant un livre illuminé et dans celui de Francfort sur-le-Mein (Lucca's Madonna) elle nourrit l'Enfant. Cette symbolique se rapporte à lamour familial, à la lumière de la science divine et la chasteté.

Le plus beau est le double portrait de Jean Arnolfini et sa femme Giovann: Cer:ami (1434, London, National Gallery), qui représente à la fois le moment de narriage contracté à la maison (matrimonium clandestinum) et la riche symbolique da l'unité, chasteté, fidelité et l'amour matrimonial.

Tout heureux après la paix conclue à Arras (1435), laquelle annonça la fin de la guerre de Cent ans, le chancelier et le dirigeant de la politique de principauté de Bourgogne Nicolas Rollin demanda à van Eyck de lui faire son portrait comme 
ex-voto en forme de l'audience devant Marie, la Reine des Cieux. De la fenêtre s'étend la vue sur la Cité Divine (Madonna d'Autun).

Un des amis de van Eyck, George van der Paele a commandé chez van Eyck un tableau votif pour l'Eglise de St. Donatien à Bruges, où il était chanoine, pour qu'il puisse, protegé par ses patrons, demander à la Mère Misericorde la grâce de santé pour son corps, épuisé par la maladie (1436).

Peu après van Eyck est parti pour Italie, où il a executé pour le fameaux aristocrate de Venise Michel Giustiniani un petit triptique de voyage avec Marie et l'Enfant, montrant au fondateur le texte de la prière en présence des patrons saint Michel et sainte Catherine, patronne des philisophes. A l'extérieur du triptique la Scène de l'Annonciation.

Ayant la conscience de la vocation chrétienne van Eyck a représenté sur le tableau de Ste Barbe une Tour-Eglise et le devoir de la construction du Royaume de Dieu en soi et dans les coeurs des autres. Sur une colline on voit Ste Barbe assise: de loin on voit la construction de la Tour, qui est son attribut et en même temps symbole de l'Eglise (1437, Anvers).

Vers la fin de la vie (1439) van Eyck a fait son dernier tableau consacré à S. Vierge Marie, Mère de Dieu, presentée au fond de rosier auprés de la fontaine de l'eau vivante, sans pourpre royale, au visage d'une femme de peuple. L'atmosphère de ce tableau est lyrique. Marie se montre comme Eleusa avec l'Enfant, l'embrassant par le cou et la tête.

Jean van Eyck comme peintre religieux a réussi à unifier le monde céleste avec le monde terrestre. Les recharches de la verité du réel qui l'entoure, ne l'éloigne pas du point de vue religieux. Le servant dans le symbolisme des objets quotidiens - il approche le ciel à la terre. 